\title{
FOREIGN EGYPT: \\ EGYPTOLOGY AND THE CONCEPT OF CULTURAL APPROPRIATION
}

Von Thomas Schneider

\section{BASIC CONSIDERATIONS}

This contribution uses the term Foreign Egypt as deliberately provocative opposite to what one might call Egyptian Egypt. ${ }^{1}$ This contrast is meant to be programmatic because it intentionally suggests another perspective to that which continues to be held on Ancient Egypt. As J.D. Ray put it: "Most of the standard histories represent Egypt as self-contained, isolated from its neighbours in the Eastern Mediterranean and the Near East, and rather static. Perhaps many of us would prefer to see it that way; after all, it is simpler". ${ }^{2}$ According to this view, Ancient Egypt, cut off from the outside world, unlike the topographically open cultural landscapes of Syria or Mesopotamia, was able to develop and flourish on its own and consequently stuck to the traditions of its historical identity. This point of view was largely in agreement with a holistic way of perceiving civilization such as advocated by one major trend of $20^{\text {th }}$ century cul-

1 An earlier version of this paper was given at the conference Kulturkontakt und Innovation - Der Einflu $\beta$ der Hyksos auf das Neue Reich, Vienna $4^{\text {th }}-8^{\text {th }}$ June 2003. I am greatly indebted to John BAINES who was so kind as to revise the english text and to comment upon an earlier draft of it.

${ }^{2}$ J. D. RAY, The Marquis, the Urchin, and the Labyrinth: Egyptology and the University of Cambridge. The Steven Glanville Lecture for 1995, in: CH. J. EyRE (ed.), Proceedings of the $7^{\text {th }}$ International Congress of Egyptologists, Cambridge, 3-9 September 1995, OLA 82, Leuven 1998, 1-17: 10.

3 For an overview of recent discussions in cultural theory cf. M. Fuchs, Der Verlust der Totalität. Die Anthropologie der Kultur, in: H. AppelsmeYer/E. Billmann-Mahecha (eds.), Kulturwissenschaft. Felder einer prozeßorientierten wissenschaftlichen Praxis, Weilerswist 2001, 18-53; GABRIELE CAPPAI, Kultur aus soziologischer Perspektive. Eine metatheoretische Betrachtung, op.cit., 54-96, R. BoRMANN, Raum, Zeit, Identität. Sozialtheoretische Verortungen kultureller Prozesse, Forschung Soziologie 115, Opladen 2001; R. LindnER, Konjunktur und Krise des Kulturkonzepts, in: L. Musner/G. WunberG (eds.), Kulturwissenschaften. Forschung - Praxis - Positionen, Wien 2002, 69-87.

${ }^{4}$ M.D. SAHLIns, Two or Three Things that I know about Culture, Journal of the Royal Anthropological Institute 5 (1999), 399-421; R. Brightman, Forget Culture: tural anthropology. In the latter, culture was conceived of as a continous and normative structure that enabled the scholar to make an overall definition of particular civilizations that could accordingly be termed "cultures". ${ }^{3}$ It has been argued, however, that this classic position has never been as exclusively rigid as maintained by its modern critics. ${ }^{4}$ The perception of Ancient Egypt in Egyptology and in society was nevertheless largely in line with this perspective. Thus, Egypt appeared to be a civilization devoid of dynamics and innovation, while the particular case of innovation from abroad was believed to be mostly late, marginal, or not decisive for its cultural profile. ${ }^{5}$ This image of an Egypt that prospered only because of its isolationism and was characterized by a high degree of stability also incorporated $19^{\text {th }}$ century theories which maintained that more recent stages of culture merely assimilated older ones, in a process termed metaphorically "legacy". ${ }^{6}$ This concept influenced much historiography on Egyptian civilization,

Replacement, Transcendence, Relexification, Cultural Anthropology 10 (1995), 509-546; M. FucHS, Der Verlust der Totalität, 43 (as n. 3.).

${ }^{5}$ Cf. J. SPIEgel, Soziale und weltanschauliche Reformbewegungen im Alten Ägypten, Heidelberg 1950, 57, who judges about Ancient Egypt that prior to the New Kingdom "sein kulturelles Eigenleben durch den Kontakt mit der Umwelt in keinem Falle tiefgehend betroffen (wurde)" and about the First Intermediate Period (n. 177): "Die Einwirkungen der Fremde bleiben in jener Zeit äußerlich und eng begrenzt und werden uns vor allem in technischen Dingen (z.B. im Kunstgewerbe) greifbar." Cf. also Dominique Valbelle who states that despite all cultural contamination of Egyptian New Kingdom elite culture with Near Eastern influence Egypt always remained "maîtresse des ces emprunts" (D. VAlbELlE, Les Neuf Arcs. L'égyptien et les étrangers de la préhistoire à la conquête d'Alexandre, Paris 1990, 198) and J. H. BREASTED, Geschichte Aegyptens, Berlin 1910, 14: "Doch boten die natürlichen Grenzen Ägyptens immer eine Scheidewand, die sich gegen Eindringlinge wirksam genug erwies, und die es den Ägyptern ermöglichte, fremde Elemente allmählich in sich aufzunehmen, ohne in ihrem eigenen Bestande gefährdet zu sein.”

${ }^{6}$ P. BuRke, Kultureller Austausch, Erbschaft unserer Zeit; Bd. 8, Frankfurt a.M. 2000, 16. 
among others John A. Wilson's The Burden of Egypt (1951) which is based on that central theme of traditionalism and marginalizes the fact of innovation. A straight line leads from here to the opinion that "no decisions of mankind were ever made in Egypt" such as maintained by Karl Jaspers in his philosophical concept of an Axial Age. ${ }^{7}$ The classification of Ancient Egypt as an example of the preaxial age has been supported by Emma Brunner-Traut and Jan Assmann. ${ }^{8}$ How thoroughly this picture has spread beyond Egyptology becomes evident if one glances at the monumental African history: from earliest times to independence by PHILIP CuRTIN et alii (1995), which states that Ancient Egypt did not know much innovation, apart from the domain of religion. ${ }^{9}$

However, critical voices have not been completely absent. ${ }^{10}$ Joachim Spiegel, in his Das Werden der altägyptischen Hochkultur (1953), claimed: "Hardly ever have the uniformity and isolation of Egyptian culture, which have been believed to be a solid axiom, been subjected to a detailed examination. Where a phenomenon has been observed to be unchanging, this has been interpreted as a quite natural persistance against which innovation, as was maintained, could only gain acceptance with difficulty. The delusion was formed of the "people which could not forget"." 11

Taking up an idea put forward by Claude LéviStrauss, Jan Assmann characterized Egypt as a prime example of a so-called "cold" society not willing to change; "civilized, literate, and organized as a state,

7 Cf. S. Breuer, Kulturen der Achsenzeit. Leistung und Grenzen eines geschichtsphilosophischen Konzepts, Saeculum 45 (1994), 1-33.

8 J. Assmann, Große Texte ohne eine Große Tradition. Ägypten als vorachsenzeitliche Kultur, in: S. N. EISENSTADT (ed.), Kulturen der Achsenzeit. Ihre institutionelle und kulturelle Dynamik, 3 vols., Frankfurt 1992, vol. 3: 245-280; E. Brunner Traut, Frühformen des Erkennens am Beispiel Altägyptens, 2nd ed., Darmstadt 1992.

9 P. Curtin, S. Feierman, L. Thomson, and J. Vansina, African History: from Earliest Times to Independence, London [etc.] 21995, 40.

10 Cf. already E. Meyer, Ältere Chronologie (1904), 70: "In geradezu vorbildlicher Weise können wir hier erkennen, wie eine stetig fortschreitende Kultur die älteren Formen überwindet und abstößt und Schritt für Schritt Neues schafft, bis die innere Geschlossenheit einer reifen Kultur erreicht ist."

11 Translated from J. SPIEGEL, Das Werden der altägyptischen Hochkultur, 1953, 4.

12 Cited from J. Assmann, Das kulturelle Gedächtnis. Schrift, Erinnerung und politische Identität in frühen Hochkulturen, München ${ }^{2} 1997,69$. but nevertheless cold insofar as it desperately resisted the invasion of history"."12 Related to this line of argumentation is the concept of "cultural memory" which memorializes and enhances the traditional structure of the Egyptian world, as well as any trauma it underwent. ${ }^{13}$ In Assmann's view, "culture" continues to be a holistic frame of reference for Egypt's entire civilization, basically a stabilizing structure made up of its essential myths and rituals. ${ }^{14}$ However, in his Sinngeschichte, he takes into account a larger degree of cultural plurality and dynamics. ${ }^{15}$

After Joachim Spiegel's severe criticism of the prevailing vision of an Egyptian traditionalism, several Egyptologists of the second half of the $20^{\text {th }}$ century have emphasized the contrary point that Egypt offers much evidence of inner dynamics. In their eyes, these dynamics brought about considerable diachronic change in Egypt, at times to such an extent that Egypt as a whole was redefined and restructured. At the beginning of his survey of Egyptian history, Erik Hornung deconstructs the old image by reminding the reader of the "ongoing, often stormy changes behind this rigid facade". ${ }^{16}$ Especially noteworthy is a recent judgment by John Baines, which represents the very opposite of the older dogmatic view when he claims that "change was of the essence in Egyptian culture as in others". ${ }^{17}$

This approach coincides with new viewpoints adopted by cultural theory during the last two decades, ${ }^{18}$ which question earlier "iron cage" concepts of culture. ${ }^{19}$ Among others, Niklas Luhmann

13 Cf. A. Assmann, Gedächtnis als Leitbegriff der Kulturwissenschaften, in: L. Musner and G. WunBerg (eds.), Kulturwissenschaften. Forschung - Praxis - Positionen, Wien 2002, 27-45, and S.J. SCHMIDT, Geschichte beobachten. Geschichte und Geschichtswissenschaft aus konstruktivistischer Sicht, ÖZG 8 (1997), 19-44 (also criticizing Jan Assmann's use of the concept of memory culture).

14 J. Assmann, Das kulturelle Gedächtnis, 78ff., 167ff.

15 J. Assmann, Ägypten. Eine Sinngeschichte, München 1996, $29 \mathrm{ff}$.

16 E. Hornung, History of Ancient Egypt, Edinburgh 1999, ix.

17 J. Baines, Temples as Symbols, Guarantors, and Participants in Egyptian Civilization, in: S. QuIRKE (ed.), The Temple in Ancient Egypt. New Discoveries and Recent Research, London 1997, 216-241, esp. 217. Cf. also R.J. Wenke, Anthropology, Egyptology, and the Concept of Cultural Change, in: J. Lustig (ed.), Anthropology and Egyptology: a Developing Dialogue, Sheffield 1997, 117-136.

18 For the following cf. the bibliographical references given in n. 3 .

19 R. Lindner, Konjunktur und Krise des Kulturkonzepts (as n. 3.), 80-83; M. Fuchs, Der Verlust der Totalität (as n. 3.). 
denied the legitimacy of a holistic interpretation of culture and postulated, in the case of functionally differentiated societies/civilizations, different subsystems with their own specific cultural codes or programs. This is obviously the case in Egypt, too. ${ }^{20}$ Clifford Geertz has put forward the concept that culture is defined by social actors through their specific actions. Civilization, thereafter, consists of various communities that define their particular culture through specific knowledge, symbols, and frames of reference. These cultures are stressed not to be static, but to result from ongoing process and change. ${ }^{21}$

One important possibility how change is stimulated is innovation from abroad. As I stressed, at the beginning, that Egypt was rather dynamic instead of being static, there is an alternative picture to the cliché of an isolationist Egypt. Emphasizing this is all the more important as Egyptology does not generally adhere to such a view. ${ }^{22}$ How openness to cultural impact was traditionally judged becomes perfectly clear in Siegfried Morenz's contrast between Greeks and Egyptians in his classic essay Der Alte Orient. Von Bedeutung und Struktur seiner Geschichte, an idealized view of the Greeks:

"There is also the fact that in general only functionaries travelled, while the average Egyptian stayed his whole life in one place, tied to his field by occupation and partially by law. Circumstances of this kind, which have hitherto been neglected, as well as the meager basis of education, must have excluded the overwhelming majority of the Egyptian people from a horizon appropriate to Egypt's external extension and inner grandeur. By comparison, the Greek nobility compensated for the narrowness of its native country with its keenness to travel and its eagerness to establish new contacts, as later did Greek merchants with their worldwide sphere of action. In doing so, Greeks [as opposed to Egyptians] reinforced a way of life that combined

${ }^{20}$ Cf. also my remarks in T. SCHNEIDER, Akkulturation Identität - Elitekultur. Eine Positionsbestimmung zur Frage der Existenz und des Status von Ausländern in der Elite des Neuen Reiches, in: R. GundLach (ed.), Der ägyptische Hof des Neuen Reiches: Seine Gesellschaft und Kultur im Spannungsfeld zwischen Innen- und Außenpolitik (Königtum, Staat und Gesellschaft früher Hochkulturen, 4), Wiesbaden (forthcoming).

21 G. CAPPAI, Kultur aus soziologischer Perspektive (as n. 3), 63; cf. also H. UHL, "Kultur" und/oder "Gesellschaft"? Zur "kulturwissenschaftlichen Wende" in den Geschichtswissenschaften, in: L. Musner/G. WUnberG (eds.), Kulturwissenschaften. Forschung - Praxis - Positionen, Wien 2002, 220-236, esp. 228f; R. BORMANn (as n. 3), 71ff., $133 \mathrm{ff}$. unquestioned loyalty to their state with a limitless willingness to learn from abroad." ${ }^{23}$

It is evident how distorted this comparison actually is: Morenz compares a lower-class Egyptian peasant not with his Greek counterpart, who was equally fixed to his land, but with nobility and merchants. But Egyptian merchants and nobility (Morenz's "functionaries") were mobile, too. Since elite culture was the focus of Egyptian civilization, for a literate Egyptian an "average" member of their civilization would have been a member of this elite, not a peasant. Elite Egyptians were committed to that "unquestioned loyalty to their state combined with a limitless willingness to learn from abroad" just as much as the Greek nobility, to which Morenz exclusively wanted to attribute such qualities.

In Egypt, learning from abroad was a constitutive element in establishing elite culture from the earliest times onwards. One should therefore replace the traditional idea of an isolationist evolution with one of cultural flexibility. On such a hypothesis, Egyptian civilization promoted and enhanced cultural contact as a stimulus to the progress of its civilization. Egypt will then owe its grandeur not to its alleged isolation against cultural influence from abroad, but, on the contrary, to its permeability to that impact. As a player in international cultural exchange Egypt will then be characterized by a particular ability effectively to incorporate and adapt innovation from abroad. Throughout its history, it will then have derived much of its dynamics as a civilization from this impact of outside influences.

This interpretation could be categorized as cultural appropriation, to use a term proposed by Michel de Certeau and Paul Ricoeur. ${ }^{24}$ Cultural appropriation means the acquisition of external ideas, objects, and practices by a given civilization. Self-evidently, this procedure changes the appearance of existing cultural repertoires. The profile of a civilization

${ }^{22}$ The reader is recommended to read J. D. Ray's lucid remarks (as n. 2). Cf. also C. Zivie Coche, Dieux autres, dieux des autres: Idendité culturelle et alterité dans l'Egypte Ancienne, in: IOS XIV (1994), 39-79, p. 39: "Bien entendu, toute l'histoire égyptienne est là pour prouver le contraire et nous montere que le pays fut perméable aux influences extérieures."

${ }^{23}$ Translated from S. Morenz, Der Alte Orient. Von Bedeutung und Struktur seiner Geschichte, in: Propyläen-Weltgeschichte. Eine Universalgeschichte, 1965, $48 \mathrm{f}$.

24 On this concept see P. BuRke, Kultureller Austausch, Erbschaft unserer Zeit; Bd. 8, Frankfurt a.M. 2000, 9-40. 
which constantly adapts and incorporates innovation shifts markedly away from its starting point. The theory of cultural appropriation speaks of the refiguration of a civilization. We may assume that Egyptian civilization and its cultural sub-codes were transformed or refigured through such appropriation. The fact that cultural transfer is so visible in New Kingdom Egypt seems itself to be the result of refiguration: only a refigured civilization can exhibit the changes it underwent. The consequence of cultural appropriation is therefore always an Egypt that is Egyptian in different ways from the Egypt which existed before the appropriation. Or, to use the formulation of the musicologist Joseph Richmond Levenson: "An audience which realizes that Mozart is not Wagner will never be able to hear the $18^{\text {th }}$ century Don Giovanni”. ${ }^{25}$

We must therefore dismiss the idea of a pure Egyptianness of Egyptian civilization, since this seems to be largely a theoretical construct: there was never an Egyptian civilization that arose without influences of some kind, while Egypt's predynastic cultures were not yet "Egyptian". The issue of foreign appropriations then raises the question of how Egyptian Ancient Egypt was and how would we define Egyptianness in terms of cultural characteristics. The answer to this question is not as self-evident as might at first appear, in view of our constant unreflecting use of the epithet "Egyptian". If we take into account the considerable changes Egypt underwent,

25 Cited after P. Burke (see n. 24).

26 H. KNIFFKA, Interkulturelle Ligaturen, in: B. HufEISEN/ M. PROKOP (eds.), Zeitschrift für Interkulturellen Fremdsprachenunterricht [Online] 2(3), Januar 1998, 27pp. Available: http://www.ualberta.ca/ german/ejournal/kniffka4.htm

27 On Egyptian glass cf. (exhaustive reference can be found in Nicholson [2000], 221-224): J.D. COONEY, Glass Sculpture in Egypt, Journal of Glass Studies 2 (1960), 10-43; J.D. COONEY, Catalogue of Eyyptian Antiquities in the British Museum, IV: Glass, London 1976; J. CuRTIS, Glass inlays and Nimrud Ivories, Iraq 61 (1999), p. 59-69; S.M. GoldsteIn, A Unique Royal Head, Journal of Glass Studies 21 (1979), 8-16; C.M. JACKSON/P.T. NiCHOLSON/W. GNEISINGER, Glassmaking at Tell el-Amarna: an Integrated Approach, Journal of Glass Studies 40(1998), 11-23; C. LILYQUIST/R.H. BRILL, Studies in Early Egyptian Glass, New York 1993; P.T. Nicholson, Egyptian Faience and Glass, Aylesbury 1993; P.T. NiCHOLSON, Glassmaking and Glassworking at Amarna: Some New Work, Journal of Glass Studies 37 (1995), 1-19; P.T. Nicholson/C.M. JACKson/K.M. Trotr, The Ulu Burun Glass Ingots, Cylindrical Vessels, and Egyptian Glass, JEA 83 (1997), 143-153; P.T. Nicholson/C.M. JaCKsOn, Kind of Blue: Glass of the any adequate answer is likely to incorporate diachronic perspective. A New Kingdom elite Egyptian certainly recognized the Old Kingdom as being Egyptian, but we may suggest that an Old Kingdom elite Egyptian would not have had a cultural understanding of New Kingdom Egypt, in view of all the refigurations Egypt incorporated.

For the particular phenomena of cultural appropriation, the sociolinguist Hannes Kniffka has coined the apt term of intercultural ligatures. ${ }^{26}$ In what follows I should like to present briefly three examples of cultural ligatures: glass, the horse, and Baal. These innovations, all of which were in origin royal prerogatives, underwent different patterns of development in terms of their cultural impact. From a technical point of view, they represent the mastery of high temperature, high speed, and ferocity. In terms of culture, they had an impact of different intensity in the spheres of status, society, and religion. In terms of the way they were appropriated, they exemplify the different roles groups and individuals played in furthering their acceptance.

\section{Three cultural Ligatures: \\ GLASS, THE HORSE, AND BAAL}

Egyptian glass, ${ }^{27}$ in Egyptian terminology "melted/ cast (precious) stone" appears in the early New Kingdom as a luxury product par excellence of the Egyptian elite. This early glass testifies to such a remarkable level of technical mastery that it seems likely to

Amarna Period Replicated, in: W.D. KINGERY/P. MCCRAY (eds.), The Prehistory and History of Glass and Glass Technology, Columbus 1998, 105-120; P.T. NICHOLSON/J. HENDERSON, Glass, in: P.T. NichOLSON/I. SHAW (eds.), Ancient Egyptian Materials and Technology, Cambridge 2000, 195-224 (lit.); B. Nolte, Die Glasgefäße im Alten Ägypten, MÄS 14, München 1968; A.L. OPPENHEIM et al., Glass and Glassmaking in Ancient Mesopotamia. An Edition of the Cuneiform Texts which Contain Instructions for Glassmakers. With a Catalogue of Surviving Objects, Corning 1970 (esp. pp. 181-184 about ist impact on Egypt); A.L. OPPENHEIM, Towards a History of Glass in the Ancient Near East, in: JAOS 93(1973), 259-266; E.B. PUSCH, Glasproduktion in Qantir, ÄEL 9 (1999), 111-119; T. REHREN, Ramesside Glass-Colouring Crucibles, Archaeometry 39 (1997), 355-368; T. Rehren/E.B. PusCh, New Kingdom Glass Melting Crucibles from Qantir-Piramesse, JEA 83(1997); E. RIEFSTAHL, Ancient Egyptian Glass and Glazes in the Brooklyn Museum, New York 1968; A.J. SHORTLAND, Vitreous Materials at Amarna. The Production of Glass and Faience in $18^{\text {th }}$ Dynasty Egypt, BAR Intern. Ser. 827, Oxford 2000; A. ShorTland, Depictions of Glass in Two Theban Tombs and their Role in the Dating of Early Glass, JEA 86 (2000), 159-161. 
have been imported from abroad; alternatively, glass workers were recruited from northern Mesopotamia or Mitanni to build up a domestic Egyptian glass industry. Though striking in terms of appearance, glass remained only a mere status accessory. Therefore it cannot be considered more than a very weak ligature in terms of cultural impact. This is also obvious with regard to the ongoing scientific discussion as to how thoroughly glass manufacturing methods were implemented in Egypt. It remains disputed when Egypt began a glass production of its own and whether it also was able to produce glass, in addition to founding and processing it, or whether it had to import raw glass. This debate has been intensified by the recovery of the Amarna period shipwreck at Ulu

28 D. Aston/E.B. Pusch, The Pottery of the Royal Horse Stud and its Stratigraphy. Preliminary Report, $\ddot{A} \mathcal{E} L 9$ (1999), 39-75; J. BoESSNECK, Ein altägyptisches Pferdeskelett, MDAIK 26 (1970), 43-47; J. BOESSNECK, Tell elDabca III. Die Tierknochenfunde 1966-1969, Wien 1976; J. BOESSNECK/A. VON DEN DrIEsch, Tell el-Dabca VII. Tiere und historische Umwelt im Nordost-Delta im 2. Jahrtausend anhand der Knochenfunde der Ausgrabungen 1975-1986, Wien 1992; W. DECKER, Ein ägyptisches Wort für Hippodrom? SAK 2 (1975), 49-54; W. DECKER, Der Wagen im Alten Ägypten, in: W. Treue (ed.), Achse, Rad und Wagen. Fünftausend Jahre Kultur- und Technikgeschichte, Göttingen 21986, 35-59.360-368; W. DeCKer/M. HerB, Bildatlas zum Sport im Alten Ägypten. Corpus der bildlichen Quellen zu Leibesübungen, Spiel, Jagd, Tanz und verwandten Themen, HdO I, 14, Leiden/New York/Köln 1994. W. Decker, Pferd und Wagen im Alten Ägypten, in: B. HÄnsel/S. Zimmer (eds.), Die Indogermanen und das Pferd. Akten des Internationalen interdisziplinären Kolloquiums Freie Universität Berlin, 1.-3. Juli 1992. Bernfried Schlerath zum 70. Geburtstag gewidmet, Budapest 1994, 259-270; A. GNIRS, Militär und Gesellschaft. Ein Beitrag zur Sozialgeschichte des Neuen Reiches, SAGA 17, Heidelberg 1996; D. GRODDECK, Ist das Etymon von wrry.t "Wagen" gefunden? GM 175 (2000), 109ff.; B. HÄNSEL/S. ZiMMER (eds.), Die Indogermanen und das Pferd. Akten des Internationalen interdisziplinären Kolloquiums Freie Universität Berlin, 1.-3. Juli 1992. Bernfried Schlerath zum 70. Geburtstag gewidmet, Budapest 1994; W. HeLCK, Ein indirekter Beleg für die Benutzung des leichten Streitwagens in Ägypten zu Ende der 13. Dynastie, JNES 37 (1978), 337-340; A. Herold, Piramesses - The Northern Capital: Chariots, Horses, and Foreign Gods, in: J. GoodNICK Westenholz (ed.), Capital Cities: Urban Planning and Spiritual Dimensions, Jerusalem 1998, 129-146; A. Herold, Streitwagentechnologie in der Ramses-Stadt: Bronze an Pferd und Wagen, Mainz 1999 (Die Grabungen des Pelizaeus-Museums Hildesheim in Qantir-Pi-Ramesse; 2); U. Hofmann, Fuhrwesen und Pferdehaltung im alten Ägypten, Diss. Bonn 1989; V. Horn, Das Pferd im Alten Orient. Das Streitwagenpferd der Frühzeit in seiner Umwelt, im
Burun (excavated between 1984-1994) which among many other products contained cobalt-dyed glass ingots, perhaps a consignment from Egypt to Anatolia. In any case, current scholarship favours a partial dependance of New Kingdom Egypt upon raw material, foreign knowhow, and glass importation. Glass is, thus, an example of a selective cultural appropriation which did not change the cultural repertoire - the style of glass objects and of the motifs of glass decoration remain Egyptian.

By comparison, the horse and chariot which were introduced to Egypt in the early $17^{\text {th }}$ century BC, represent a cultural ligature of far-reaching consequences. $^{28}$ Their implications were irreversible. The process of appropriation of horse and chariot lasted

Training und im Vergleich zum neuzeitlichen Distanz-, Reitund Fahrpferd, Hildesheim 1995; J. LECLANT, Astarte à cheval d'après les représentations égyptiennes, Syria 37 (1960), 1-67; M.A. LitTauer/J.H. Crouwel, Wheeled Vehicles and Ridden Animals in the Ancient Near East, HdO VII 1.2 B, Leiden/Köln 1979; M.A. LitTauer/J.H. CrouwEL, Chariots and Related Equipment from the Tomb of Tut ${ }^{c}$ ankhamūn, TTS VIII, Oxford 1985; E. MASSON, L'art de soigner et d'entraîner les cheveaux. Texte hittite du maître écuyer Kikkuli, Lausanne 1998; W. MEsSERSCHMIDT, Der ägäische Streitwagen und seine Beziehung zum Nordeurasisch-vorderasiatischen Raum, Acta Praehistorica et Archaeologica 20 (1988), 31-44; W. NAGEL, Der mesopotamische Streitwagen und seine Entwicklung im ostmediterranen Bereich, Berlin 1966; W. NAGEL, Das Aufkommen des Klassischen Streitwagens *wròta- in Syrien und Ägypten, in: W. NAGEL/C. EDER, Altsyrien und Ägypten, DamMitt 6 (1992), 1-108; 67-8; E. NeU, Zur Datierung der hethitischen Pferdetexte, in: H.A. Hoffner/G.M. Beckman (Hrg.), Kaniçcuwar. Studies in Honour of Hans Gustav Güterbock, Chicago 1986, 151-163; R. PARTRIDGe, Transport in Ancient Egypt, London 1996; E. Pusch, "Pi-Ramesse-geliebt-von-Amun, Hauptquartier Deiner Streitwagentruppen”. Ägypter und Hethiter in der Delta-Residenz der Ramessiden, Pelizaeus-Museum Hildesheim; Die ägyptische Sammlung, Mainz 1993, 126-143; P. Raulwing, Pferd und Wagen im Alten Ägypten: Forschungsstand, Beziehungen zu Vorderasien, interdisziplinäre und methodenkritische Ansätze, Teil I, in: GM 136 (1993), 71-83; P. RAulwing, Ein indoarischer Streitwagenterminus im Ägyptischen? Kritische Bemerkungen zur Herleitung der Wagenbezeichnung wrrij.t aus einem für das indoarische Sprachcorpus erschlossenen Nomen *wròta- "Streitwagen”, in: GM 140 (1994), 71-79; P. Raulwing, Neuere Forschungen zum Kikkuli-Text. Eine kleine Bestandesaufnahme trainingsinhaltlicher Interpretationen zu CTH 284 vier Jahrzehnte nach A. Kammenhubers Hippologia Hethitica, in: P. ANREITER/ERzsÉBET JerEM (eds.), Studia Celtica et Indogermanica. FS für W. Meid zum 70. Geburtstag, Budapest 1999, 351-364; P. Raulwing, 
an extremely long time, four centuries from its introduction to Egypt to the Ramesside chariotry. During the greater part of this period, horse and chariot were mainly a status accessory of the king and the elite and their military function was of secondary importance. Its primary domain was initially the experience of high speed and mobility that was integrated in the traditional domains of hunting, physical prowess, sport, official display, subduing and presenting enemies, and royal and elite life-style. The king stresses his prerogative over this appropriation by being characterized as a hippologist. ${ }^{29}$ During the $18^{\text {th }}$ dynasty, this cultural appropriation which was firmly established in the particular cultural environments of the royal court, elite culture, and urban centers assumed additional functions. In terms of social history, horse and chariot became the catalyst of a new, military segment of society and of a remodelling of its mentality. The establishment of a chariot division was the stimulus for restructuring the army and forming a class of soldiers with their own cultur-

Horses, chariots and Indo-Europeans: foundations and methods of chariotry research from the viewpoint of comparative Indo-European linguistics, Budapest 2000, Archaeolingua. Series minor; 1; C. RommelaERE, Les chevaux du Nouvel Empire égyptien. Origines, races, harnachement, Bruxelles 1991, 89-95; T. SCHNEIDER, Zur Herkunft der ägyptischen Bezeichnung wrry.t "Wagen". Ein Indiz für den Lautwert von $<\mathrm{r}>$ vor Beginn des Neuen Reiches, in: $G M$ 173 (1999), 155-158; F. STARKe, Ausbildung und Training von Streitwagenpferden. Eine hippologisch orientierte Interpretation des Kikkuli-Textes, StBoT 41, Wiesbaden 1995; A.-P. Zivie, Cavaliers et cavalerie au Nouvel Empire: á propos d'un vieux problème, in: Mélanges G.E. Mokhtar II, Le Caire 1985, 379-388; J. ZEIDLER, Zur Etymologie von wrry.t 'Wagen'. Mit einigen Bemerkungen zur 'syllabischen Schreibung', GM 178 (2000), 97-111.

29 Cf. e.g. a gem of Amenophis II; Urk. IV 1541; NeLSON, Medinet Habu II, 109.

30 Ph. Collombert/L. Coulon, Les dieux contre la mer. Le début du "papyrus d'Astarté" (pBN 202), BIFAO 100 (2000), 193-242.

31 For literature on this subject cf.: C. Bonnet, Astarté: dossier documentaire et perspectives historiques (Collezione di studi fenici 37 = Contributi alla storia della religione fenicio-punica 2), Roma 1996; P. BordreuIL/D. PARdeE, Le combat de Bacalu avec Yammu d'après les textes ougaritiques, MARI 7 (1993), 63-70; G. Colbow, Die kriegerische Istar. Zu den Erscheinungsformen bewaffneter Gottheiten zwischen der Mitte des 3. und der Mitte des 2. Jahrtausends, München 1991; PH. CollomberT/ L. Coulon, Les dieux contre la mer. Le début du "papyrus d'Astarté" (pBN 202), BIFAO 100 (2000), 193-242; I. Connelius, The Iconography of the Canaanite gods Reshef and Ba'al : Late Bronze and Iron Age I periods al code. The new cursus honorum opened up a perspective of social advancement alongside state bureaucracy. In terms of technology, building up and maintaining the new corps created new industries such as are now documented archaeologically at Qantir. In terms of religious ideology, the appropriation of horse and chariot led to the borrowing of Astarte as a goddess who protected the royal horses and chariot. In sum, the introduction of horse and chariot to Egypt formed a nucleus of long-term change in a multitude of domains affected by it.

A more dramatic case of cultural appropriation, however, has now turned up with the recovery of the first page of the so-called Astarte papyrus ${ }^{30}$ in the archives of the Bibliothèque National in Paris (Pap. Bibliothèque Nationale 202), in 2000. From the mentions of Astarte and Yam in the fragments of the long-known Astarte papyrus itself it could be inferred that it belonged to an Egyptian version of the Canaanite myth about Baal's fight against the sea. ${ }^{31}$ In the Middle Kingdom, parts of this myth ${ }^{32}$

(c. 1500-1000 BCE), OBO 140, Fribourg/Göttingen 1994; J.M. DuRAND, Le mythologème du combat entre le dieu de l'orage et la mer en Mésopotamie, MARI 7 (1993), 41-61; W. Helck, Zur Herkunft der Erzählung des sog. "Astarte-Papyrus", in: M. GörG (ed.), Fontes atque pontes. FS Helmut Brunner, ÄAT 5, 1983, 215-223; E. PoradA, The Cylinder-Seal from Tell el-Dabca, AJA 88 (1984), 485-488; D.B. REDFORD, The Sea and the Goddess, in: S. Israelit-Groll (ed.), FS Miriam Lichtheim, 1990, 824-835; H. Rowland Page, The Myth of Cosmic Rebellion. A Study of its Reflexes in Ugaritic and Biblical Literature, VTS LXV, Leiden/New York/Köln 1996, 51-109; M. SmITH, The Ugaritic Baal Cycle, Vol. 1, VTS 55, Leiden/New York/Köln 1994; M. SмIтH, The God Athtar in the Ancient Near East and his Place in KTU 1.6.I, in: Z. ZeVIT et al. (eds.), Solving Riddles and Untying Knots: Biblical, Epigraphic, and Semitic Studies in Honor of J.C. Greenfield, Winona Lake 1995; C. UeHLINGER, Leviathan und die Schiffe in Ps 104, 25-26, Biblica 71 (1990), 499-526; N. WHYATt, Art. Asherah, in: K. VAN DER ToOrn/B. Becking/P.W. van DER Horst (eds.), Dictionary of Deities and Demons in the Bible, Leiden etc./Grand Rapids etc. ${ }^{2} 1999,99-105$; N. WhyATT, Art. Astarte, in: K. VAN DER TOORN/B. BECKING/P.W. VAN DER HORST (eds.), Dictionary of Deities and Demons in the Bible, Leiden etc./Grand Rapids etc. ${ }^{2} 1999$, 109-114.

32 A. GNIRS, Die levantinische Herkunft des Schlangengottes, in: H. Guksch/D. Polz (ed.), Stationen. Beiträge zur Kulturgeschichte Ägyptens. Rainer Stadelmann gewidmet, Mainz 1998, 197-209. For an Egyptian acquaintance with the myth in the Old Kingdom s. T. SchneIder, Wer war der Gott "Chajtau"? in: K.M. Cialowicz/J.A. Ostrowski (ed.), Les civilisations du Bassin Méditerranéen. Hommages à Joachim Sliwa, Cracovie 2000, 215-220. 
seem already to have been adapted for an Egyptian audience in the story of the Shipwrecked Sailor, but in a largely remodeled and selective form. Obviously, the $18^{\text {th }}$ dynasty Egyptian audience which accepted the Baal tale such as preserved in Pap. Amherst 9/Pap. BN 202 almost in its original form and content, and very different from the adapted Middle Kingdom version was no longer the same audience but a refigured one. ${ }^{33}$ The point which is crucial is that the beginning of the text offers an embedding of the tale and so proves a cultural appropriation to the very heart of the Egyptian civilization, which has generally been believed to be immune from innovation from abroad.

Very probably, this text - entitled "New copy of what he (Baal = Seth) did for the Ennead (of gods) in order to vanquish the sea" and dated to a precise day in the $5^{\text {th }}$ regnal year of Amenophis II - is to be connected with the inauguration of the Astarte sanctuary in Perunefer in Amenophis' II $5^{\text {th }}$ year, for which stone was cut in the Tura quarries a year earlier. The hero of the story is Seth/Baal, armed for battle, with bow and horned helmet, walking across the mountains. Just as the Canaanite text actually recounts how Baal gains the kingship, the Egyptian version seems to sketch Baal as a prototype of belligerent kingship. Evidently, the Canaanite Baal was promoted to be a god of the Egyptian kingship by Amenophis II !

This evidence of innovation from abroad is most striking because traditional Egyptology assumed that the core of Egyptian civilization, the cultural frame formed by such domains as religion and kingship, was immune from innovation and not affected by change. We now see that it was the very representative of Egyptian kingship, Amenophis II, who changed its cultural code, and he redefined it on a non-egyptian model.
In addition to these cultural implications, the Paris papyrus offers new insight into Egyptian $18^{\text {th }}$ dynasty cultural politics. It now becomes plausible, and is substantiated by the presence of the $18^{\text {th }}$ dynasty state at Auaris (notably the Haremhab sanctuary that replaced an earlier one and the recently found $18^{\text {th }}$ dynasty palace), that there was continous political support for Seth-Baal throughout the $18^{\text {th }}$ dynasty. The well-known, if historically unfounded invective of Hatschepsut against the Hyksos, who allegedly had not worshipped Re, now appears in a different light. ${ }^{34}$ It is a voice in the contemporary political discussion about which god should be the supreme god of Egyptian kingship: Re, Amun, Ptah, or Seth-Baal. Unexpectedly, the Hatshepsut and Amenophis II texts appear to reflect two opposing sides of a contemporary Egyptian cultural debate: the positions of fostering traditional identity or opening up core ideologies to cultural appropriation. Foreign influence and cultural change was a crucial issue at the Egyptian court. ${ }^{35}$

To sum up, the historiographic concept of a foreign Egypt responds to three desiderata of Egyptology. It initiates, first, a general debate about the Egyptological concept of culture. It favors, second, a picture of Egypt that shows up not its common features but its diversity: a complex society with multiple cultural codes; a plurality of cultural phenomena; ongoing change caused by innovation which to a considerable extent is appropriation from abroad. And third, it pleads in favor of descriptions of Egypt as a culture that changed markedly through time by means of continous refiguration. Modern historiography of Ancient Egypt faces the challenge of describing not one single Egypt, but a sequence of different Egypts, each of a different Egyptianness.

\footnotetext{
33 The estimations of the original size of the text run to about 70 pages in the Late Egyptian Stories layout exceeding by far the length of any other known LateEgyptian tale. Could Canaanite literature have given birth to a new genre of Egyptian literature ?

34 Cf. Assmann, Moses the Egyptian. The Memory of Egypt in Western Monotheism, Cambridge/Mass. 1997, 48.

35 Cf. again SPIEgEL's statement (Soziale und weltan-
}

schauliche Reformbewegungen im alten Ägypten, Heidelberg 1950, 59) about Egypt's "bewußte und freiwillige Aufnahme des Fremden in den innersten ägyptischen Lebenskreis (...) Ägypten wird nicht von dem Andringen der Umwelt überwältigt. Aus innerer Notwendigkeit seiner Entwicklung heraus eignet es sich vielmehr das Fremde an. Es gibt sich damit selbst eine neue Basis seiner Lebensgestaltung." 
